九州大学学術情報リポジトリ

Kyushu University Institutional Repository

\title{
DESCRIPTIONS AND SOME BIOLOGICAL NOTES OF TWO NEW SPECIES OF THE GENUS PERICLISTUS FijRSTER FROM JAPAN (HYMENOPTERA, CYNIPIDAE)
}

Taketani, Akihiko

Yasumatsu, Keizo

https://doi.org/10.5109/2361

出版情報: ESAKIA. 8, pp.1-11，1973-05-31. Hikosan biological laboratory，Faculty of Agriculture, Kyushu University バージョン：

権利関係 : 


\title{
DESCRIPTIONS AND SOME BIOLOGICAL NOTES OF TWO NEW SPECIES OF THE GENUS PERICLISTUS FÖRSTER FROM JAPAN (HYMENOPTERA, CYNIPIDAE)*
}

\author{
By
}

\section{Akihiko Taketani and Keizô Yasumatsu}

The genus Periclistus Förster has been unrecorded from Japan. It is a generally known fact that the species belonging to this genus are the common inquilines in the galls of the genera Diplolepis Geoffroy and Diastrophus Hartig. They are black species, with the legs reddish-yellow, the abdomen blackish or brownish, and the mesothorax pilose.

In 1962, the senior author collected many specimens of this genus which were bred from the galls of Diplolepis japonica (Walker) at Sasayama, Hyogo Prefecture. In addition, he had a good chance to make some biological observations with them. The specimens are represented by two new species, one being blackish and another brownish.

Before going further the authors wish to express their sincere thanks to Mr. J. Quinlan of the British Museum (Natural History), London and Dr. B. D. Burks of the National Museum of Natural History, Washington, D. C. for their kind suggestions and assistance in comparing the specimens with the related species of the genus in their collections, The senior author also expresses his hearty thanks to Dr. S. Momoi of Kôbe University and Mr. F. Kobayashi of Kansai Branch, Government Forest Experiment Station for their kind suggestions.

\section{Genus Periclistus Förster}

Aylax (part.) Hartig, 1840, Z. Ent. Germar, 2: 186, 195.

Periclistus Förster, 1869, Verh. Ges. Wien, 19: 332, 337.

Periclistus, Ashmead, 1885, Trans. Amer. Ent. Soc., 12: 297.

This genus is characterized and distinguished from the other genera in having the following structures : Antennae, $+12-, \sigma^{7} 14$-segmented, filiform, the third segment usually shorter than the fourth ; face striolate laterally; pronotum with two diverging carinae; mesothorax finely punctate or alutaceous, pubescent ;

* Contribution from the Entomological Laboratory, Faculty of Agriculture, Kyushu University, Fukuoka. 
notaulices straight and parallel; scutellum with two well-marked foveae; propodeum with two parallel carinae; radial cell opened anteriorly; anterior claws bidentate; second and third gasteric segments united.

\section{Key to the closely related species}

1. Notaulices complete, though sometimes faint; mesopleuron striate ; female with gasteric segment 2-3 with a complete apical band of fine punctures. .. . . . . .............. . brandtii Ratzeburg

- Notaulices complete; mesopleura broad, smooth and shining. . . . . . . . . . . . . . . . . . . . . natalis sp. nov. and quinlani sp. nov.

- Notaulices incomplete, absent anteriorly ; mesopleuron with a bare shining patch dorso-posteriorly or almost smooth; gasteric segment $2+3$ with apical punctures sometimes absent dorsally. $\ldots \ldots \ldots \ldots \ldots \ldots \ldots$

2. Mesopleuron mainly striate, with a smooth shining patch posteriorly ... ..................... c... carinae Hartig

- Mesopleuron almost entirely smooth and polished, with faint striae only ventrally $\quad \ldots \ldots \ldots$ spinosissimae Dettmer

Periclistus natalis and $\boldsymbol{P}$. quinlani would run to $P$. bmndtii if we regard the notaulices and the striation of mesopleura as important characters for separating the species groups. The presence or absence of punctures on the apical margin of the gasteric segment $2+3$ is also an important character that enables $P$. brandtii to be separated from the remainder. $P$. natalis and $P$. quinlani would differ on the sculpture of mesopleura not being striate and on the same of mesonotum not being dull, but reticulate to reticulate-rugose with foveae. In $P$. brandtii the third segment of the antenna is gently curved and less swollen at the apex than in $P$.natalis, and rather similar to $P$. quinlani, but the curve being more uniform. The carinae on the propodeum in $P$. natalis and $P$. quinlani are parallel, but in $P$. brandtii and $P$. spinosissimae they are curved outwards. $P$. rosarum Dettmer would seem to be closely related to $P$. carinae and $P$. spinosissimae by the incomplete notaulices and the delicately striated mesopleura judging from their descriptions.

\section{Periclistus natalis sp. nov.}

․ Head black; mandibles and three basal segments of antennae brown, 4-12 segments of antennae dark brown; ocelli and palpi yellowish brown. Thorax black ; tegulae, legs and veins brown. Abdomen reddish-brown; petiole black, $2+-3$ gasteric segment reddish-brown and the posterior margin of each of the following ones and sheath dark brown.

Head transverse, slightly wider than thorax ; occiput and vertex smooth, shining and sparsely haired; orbits except inner margins smooth and shining, with sutures heavily convergent to clypeus; frons longitudinally elevated in the middle and more or less depressed laterally, densely haired; cheeks smooth and covered with long hairs. Antenna 12-segmented; three basal segments sparsely pubescent 
and the remaining segments densely pubescent; third segment always shorter than the fourth, twelveth the longest; relative lengths (widths) of antenna1 segments as follows-I : II : III : IV : V : VI : VII : VIII : IX : X : XI : XII= 11.8(4.5): $6.0(3.5): 10.0(2.8): 11.0(3.0): 11.0(3.0): 10.5(3.0): 9.5(3.0): 9.0(3.0): 9.0(3.0): 7.5(3.0): 7.0$ (3.0) : $15.0(3.0)$.

Pronotum very broad, $5 / 8$ as long in median dorsal line as the widest part of its posterior margin, matted, finely punctured, sparsely haired in the middle, but densely haired laterally. Mesonotum shining, punctured and pubescent; notaulices shallow but distinct, and a median scutal line faintly present posteriorly. Scutellum slightly wider than long, coarsely carino-reticulate, densely haired, and the anterior foveae smooth and shining. Mesopleura broad, smooth and shining with the underside sparsely haired and broadly and longitudinally concave in the middle. Propodeum foveate, sparsely haired in the middle and densely haired, reticulate laterally, with two distinct straight carinae ; foveae smooth and shining, space between foveae smooth and shining.

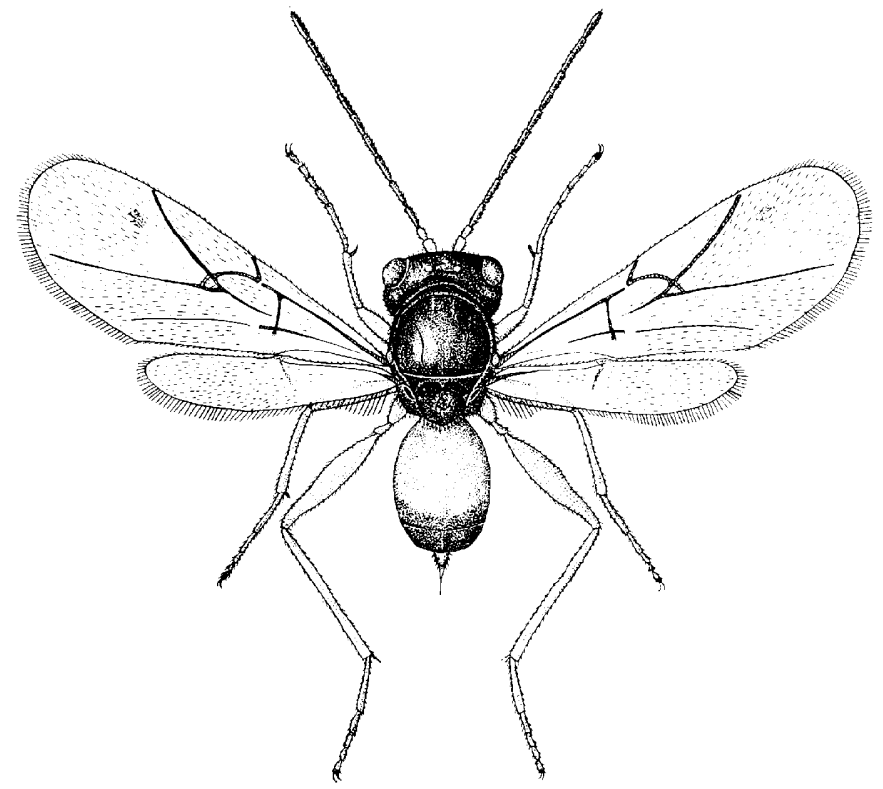

Fig. 1. Female of $P$. natalis.

Wings hyaline, densely covered with short microtrichiae which are much denser on the apical half than the basal half; radial cell opened anteriorly, with a small clouded macula posterior to the anterior margin near the apex of radial cell; anterior and apical margins of fore wings and the posterior margin of hind wings fringed with ciliate pubescence ; venation as shown in Fig. 1. Tarsal claws strongly lobed. 
Abdomen smooth, shining, naked but faintly sculptured; basal portion of the second gasteric segment, posterior margin of each of the sixth and the following gasteric segments, underside of hypopygium and sheath sparsely haired. Relative lengths of head, antenna, mesonotum and fore wings as $1: 2.3: 0.8: 3.1$.

Length of body: 1.0-1.2 $\mathrm{mm}$.

$\sigma^{7}$. Differs from the female as follows-Antennae 14-segmented, relative lengths (widths) of antennal segments-I : II : III : IV : V : VI : VII : VIII : IX : X : XI : XII : XIII : XIV= $11.0(4.5): 5.5(3.0): 10.0(3.0): 9.5(2.5): 9.0(2.5): 8.8(2.7): 8.0(3.0):$ $7.0(2.5): 5.5(3.0): 5.5(3.0): 5.0(3.2): 5.0(3.0): 9.2(3.0)$. Third segment longer than fourth and swollen apically. Gasteric tergites 2 and 3 not fused completely, dark brown. Relative lengths of head, antenna, mesonotum and fore wing as $1: 2.7$ : $0.9: 3.7$.

Length of body: $080.9 \mathrm{~mm}$.

Holotype: $q$ (Type No. 2004, Kyushu Univ.), Sasayama, Hyogo Prefecture, 16. vi. 1962, A. Taketani leg.

Paratypes : 22 o o 19 우우 16. vi. 1962, 5 o o o $^{7} 18$ 웅, 14-20. vi. 1966, Sasayama, Hyogo Prefecture, A. Taketani leg.

Besides the authors examined some specimens from Shikoku and Kyushu.

Distribution : Japan (Honshu, Shikoku and Kyushu).

Host: Galls of Diplolepis japonica (Walker) (Host plant: Rosa polyantha Sieb. et Zucc.).

\section{Periclistus quinlani sp. nov.}

This species resembles closely P. natalis, but differs from it in the following points.

오. Legs brown; basal $2 / 3$ of coxae, tibiae and first metatarsus of hind legs dark brown or blackish-brown. Abdomen blackish-brown except for brown sheath and ovipositor. Space between foveae of propodeum not divided completely into two cells, somewhat faintly reticulated. Relative lengths (widths) of antennal segments-I : II : III : IV : V : VI : VII : VIII : IX : X : XI . XII $=10.5(4.0)$ : $5.5(3.5): 9.2(2.5): 11.0(3.0): 10.5(3.0): 10.0(3.0): 9.0(3.0): 8.0(3.5): 8.0(3.0): 6.0(3.0): 5.5$ (3.0):12.5(3.0). Relative lengths of head, antenna, mesonotum and fore wing as. $1: 2.1: 0.7: 3.1$.

Length of body: $1.2-1.3 \mathrm{~mm}$.

${ }^{7}$. Abdomen black except penis. Relative lengths (widths) of antennal segments-I : II : III : IV : V : VI : VII : VIII : IX : X: XI : XII : XIII :XIV $=10.0(5.0)$ : $5.0(3.0): 9.5(3.0): 9.0(2.5): 9.0(3.0): 8.5(3.0): 7.5(2.5): 7.0(3.2): 6.5(3.2): 5.5(3.5): 5.2(3.5):$ $5.0(3.5): 4.5(3.5): 8.0(3.2)$. Third antennal segment more swollen at the apex than in P. natalis. Relative lengths of head, antenna, mesonotum and fore wing as $1: 2.5: 0.8: 3.5$.

Length of body: $1.0-1.1 \mathrm{~mm}$.

Holotype: ㅇ (Type No. 2005, Kyushu Univ.), Sasayama, Hyogo Prefecture, 21. v. 1962, A. Taketani leg.

Paratypes: $8 \sigma^{\nearrow} \overbrace{}^{\nearrow} 15$ 웅, 21. v. 1962, 20 지 25 우우, 3. vi. 1962, Sasayama, Hyogo 
Prefecture, A. Taketani leg., 16 ㄲㄲ 2 우우, 2. v. 1966, Mt. Hiko, Fukuoka Prefecture, A. Taketani leg.

The authors examined some specimens from Shikoku.

Distribution : Japan (Honshu, Shikoku and Kyushu).

Host: Galls of Diplolepis japonica (Walker) (Host plant: Rosa polyantha Sieb. et Zucc.).

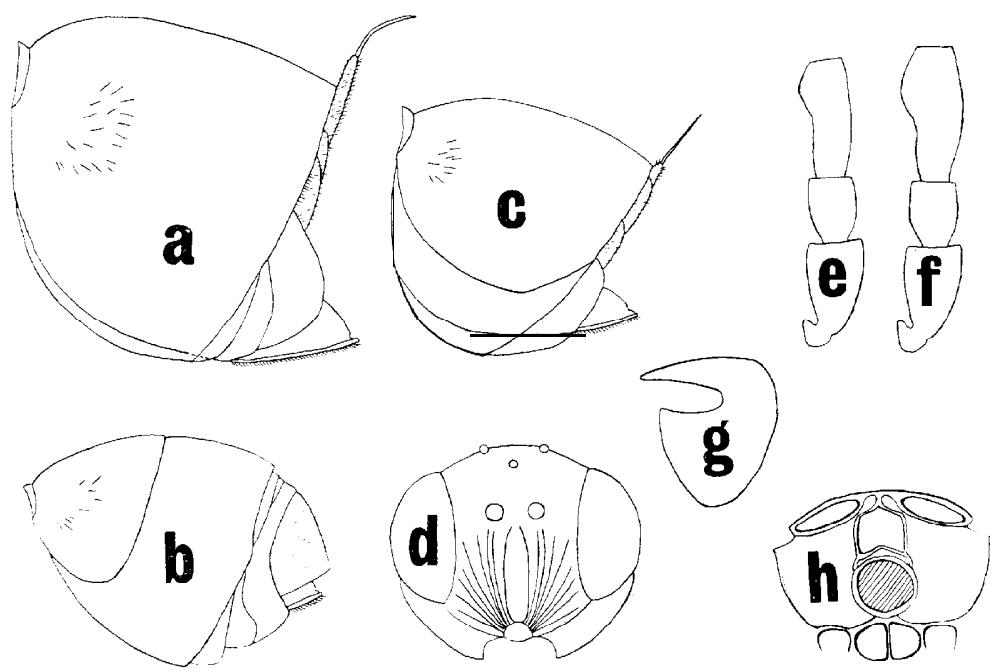

Fig. 2. a-c.- -abdomen: a, P. quinli, 우 b, P. quinli, o ; c, P.natalis, ‥ d- frontal view of face, P.natalis, 오. e-f. - -three basal segments of antenna, $\sigma^{7}$ : e, P. quinli; f, P.natalis. g- tarsal claw of P. quinli. h -propodeum of $P$. natalis, 우.

The authors could not find the emergence of these two inquiline wasps from any galls formed on Rosa rugosa Thunb. by Diplolepis japonica (Walker).

The type-specimens of these new species will be preserved in the collection of the Entomological Laboratory, Faculty of Agriculture, Kyushu University.

\section{Biological observations}

In 1962, many galls were collected when they had shed from the leaves of Japanese rose plant during the summer season at Sasayama, Hyogo Prefecture. They were preserved in the transparent envelopes with numbers attached to collect the wasps in the next year. To estimate the volume of galls, three dimentions (width, length and hight) of the gall were measured by a slide calipers.

In 1965, about 900 galls were collected on Mt. Hiko, Fukuoka Prefecture. They were also preserved in the same kind of envelopes. At the same time two dimentions (width and height) of the gall were measured by a slide calipers. 


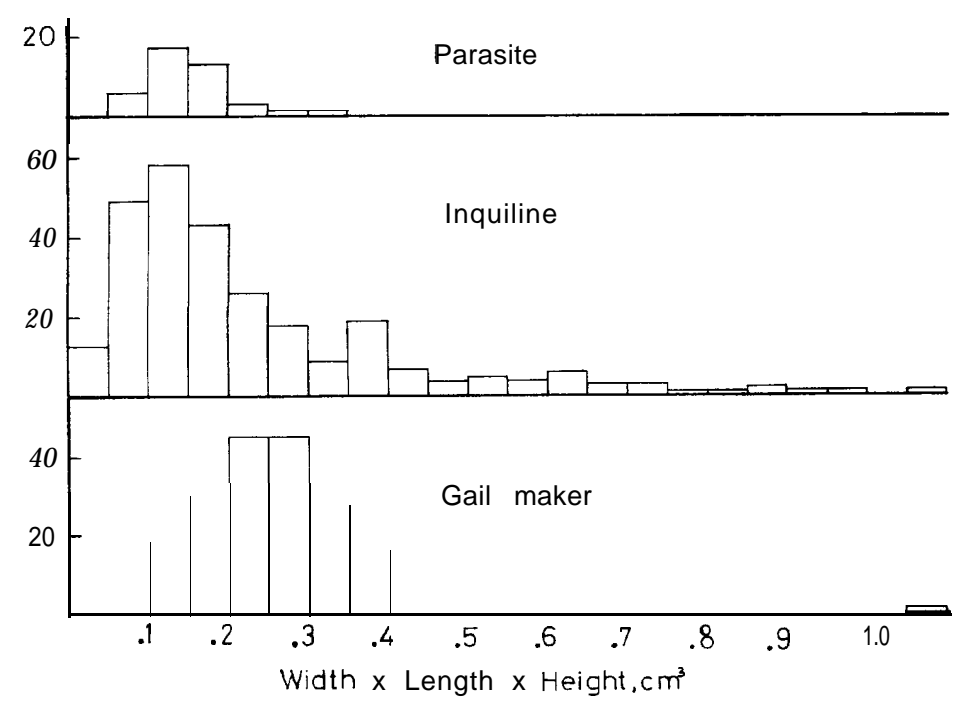

Fig. 3. Frequency distribution of the gall caused by $D$. japonica; parasites, inquilines and gall maker respectively (1963 - at Sasayama).

In the spring of 1966, emergence of many individuals of the gall maker, inquilines, Chalcid- and Ichneumon-flies was observed in the envelopes. Just after emergence the females of $\mathrm{P}$. natalis were dissected with the help of forceps and sharp pointed needles under the binocular microscope. The number of ovarioles and ovarian eggs was counted and measured with the same apparatus. Some of the females after mating were released in the glass cylinder to which the young wild rose plant with many galls caused by Diplolepis were provided. Some observations were made on the development of galls.

\section{Biological differences between $P$. natalis and $P$. quinlani.}

Remarkable differences were observed between the biologies of P. natalis and $P$. quinlani. (1) The first was the difference in the emergence of adult wasps. In $P$. natalis, the emergence was ranged from the beginning of June to June 20th, while in $P$. quinlani from May 6th to June 4th. Of course, the date of emergence varies with the district, temperature, moisture and so on, but the overlapping of the peaks of their emergence and the emergence of the two species from the same gall have never been observed. (2) The second difference was the size and the frequency distribution of the galls. In $P$. natalis the size was ranged from $0.2 \mathrm{~cm}^{2}$ to $1.4 \mathrm{~cm}^{2}$ and its distribution was rather even, but in $P$. quinlani the size was ranged from $0.1 \mathrm{~cm}^{2}$ to $0.8 \mathrm{~cm}^{2}$ and its distribution showed a conspicuous peak. (3) The third difference was the frequency distribution of the size of larval cells. In $P$. natalis, it showed no conspicuous peak, making the contrast to that of $P$. quinlani. 


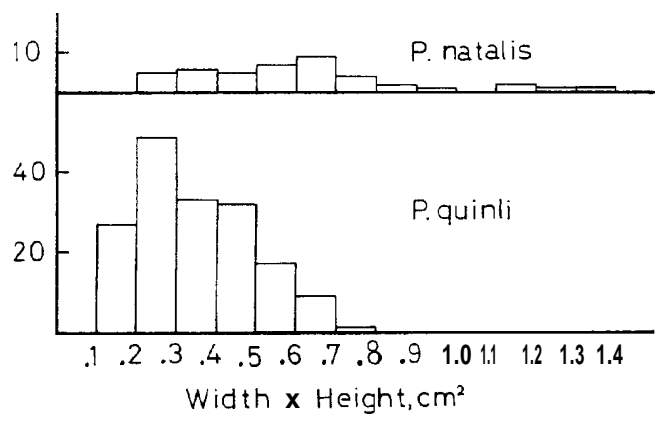

Fig. 4. Frequency distribution of the gall which was attacked by inquilines, P.natalis and P.quinli(1965 - on Mt. Hiko).

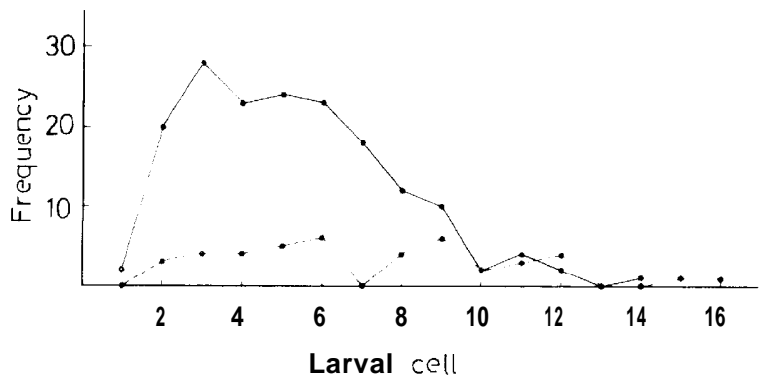

Fig. 5. Frequency distribution of larval cell, .----0 P.natalis, $\mathbf{p}=\mathbf{P}$. quinli (1965- on Mt. Hiko).

Protection wall surrounding the block of larval cells of the inquiline wasps begins to develop immediately after the hatching of inquiline eggs, and the larval cells are formed. As the emergence of $P$. quinlani is about 10 or more days earlier than P.natalis, the female of P.natalis is not able to oviposit her eggs in the gall which is protected by the hard wall surrounding the larval cells of $P$. quinlani. This seems to be the most important factor controlling the emergence of the two species from the same gall.

Frequency distribution of the size of galls would suggests that the female of $P$. quinlani oviposits her eggs on the galls at random, but the oviposition of the female of $P$.natalis is restricted by $P$. quinlani population. It appears that in oviposition the female of inquiline wasp has the ability of determining or controlling her egg numbers with the size of each gall. This assumption is derived from the correlation found between the size of gall and the number of larval cells, i.e. in P. natalis $r=0.58$ and in $\boldsymbol{P}$. quinlani $r=0.55$. The values of correlation remain rather low, because the measurement was made on the completely matured galls. If the measurement could be done just after the oviposition of the female inquiline wasp, the values would be much higher than 


\section{8}

those given above.

Growth and development of galls.

The galls which were attacked by the inquilines Periclistus spp. become irregular in shape and contain several smaller cells which are fused with each other by spongy tissue instead of having one large cell as in the healthy gall. Development of the larval cell of P.natalis is shown in Fig. 3: (a) inquiline female oviposits her eggs in the nutrient zone through the parenchyma tissue. (b) after hatching the larvae begin to feed, and the larval cells of inquilines are formed. Protection wall of the inquiline larvae is also formed. Growth of the gall stops. (c, d) larva of the gall maker disappears, larval cell of the inquiline grows and develops, and the cells are fused with each other by spongy tissue.

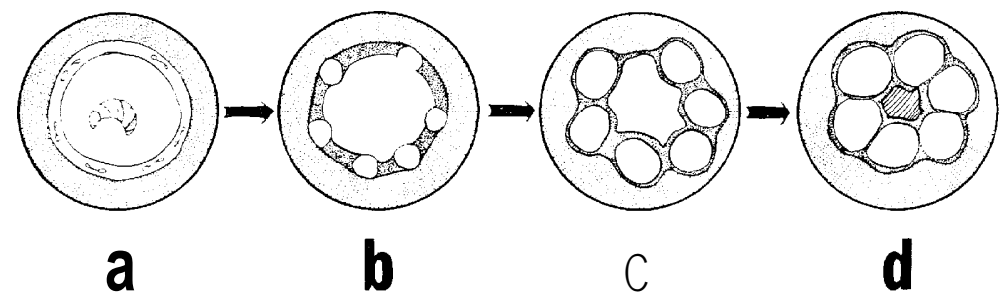

Fig. 6. Schematical presentation of the development of the gall which is attacked by $P$. natalis.

The galls which were parasitized by the species of Chalcid-flies, i.e. Eurytoma sp. or Tetrastichus sp. remain small, as the larva of gall maker can not feed actively inside the gall. Sometimes an Ichneumon-fly attacks the gall. As the Ichneumon-fly attacks comparatively the later stage of the larva of gall maker, the gall becomes larger, measuring about $0.8-1.0 \mathrm{~cm}$ in diameter.

\section{Ovary and ovarian eggs.}

The ovarian egg is typical of those found in most of the Cynipidae. It is composed of a large ovoid body (egg proper), about the same-sized elliptical body (bulb) and a narrow stalk or pedicel connecting the former two parts. In these two species, the bulb is larger than another Cynipid wasps. The egg of $P$. quinlani is slightly larger than $P$. natalis. The measurements of the ovarian eggs are as follows:

$\begin{array}{lll} & \text { P. natalis } & \text { P. quinluni } \\ \text { Length of bulb } & 0.277 \mathrm{~mm} & 0.212 \mathrm{~mm} \\ \text { Width of bulb } & 0.070 & 0.095 \\ \text { Length of stalk } & 0.248 & 0.345 \\ \text { Length of egg proper } & 0.337 & 0.403 \\ \text { Width of egg proper } & 0.088 & 0.115 \\ \text { Total length } & 0.861 & 0.960\end{array}$


Table 1. Individual variation of the number of ovarioles and eggs of Periclistus natalis.

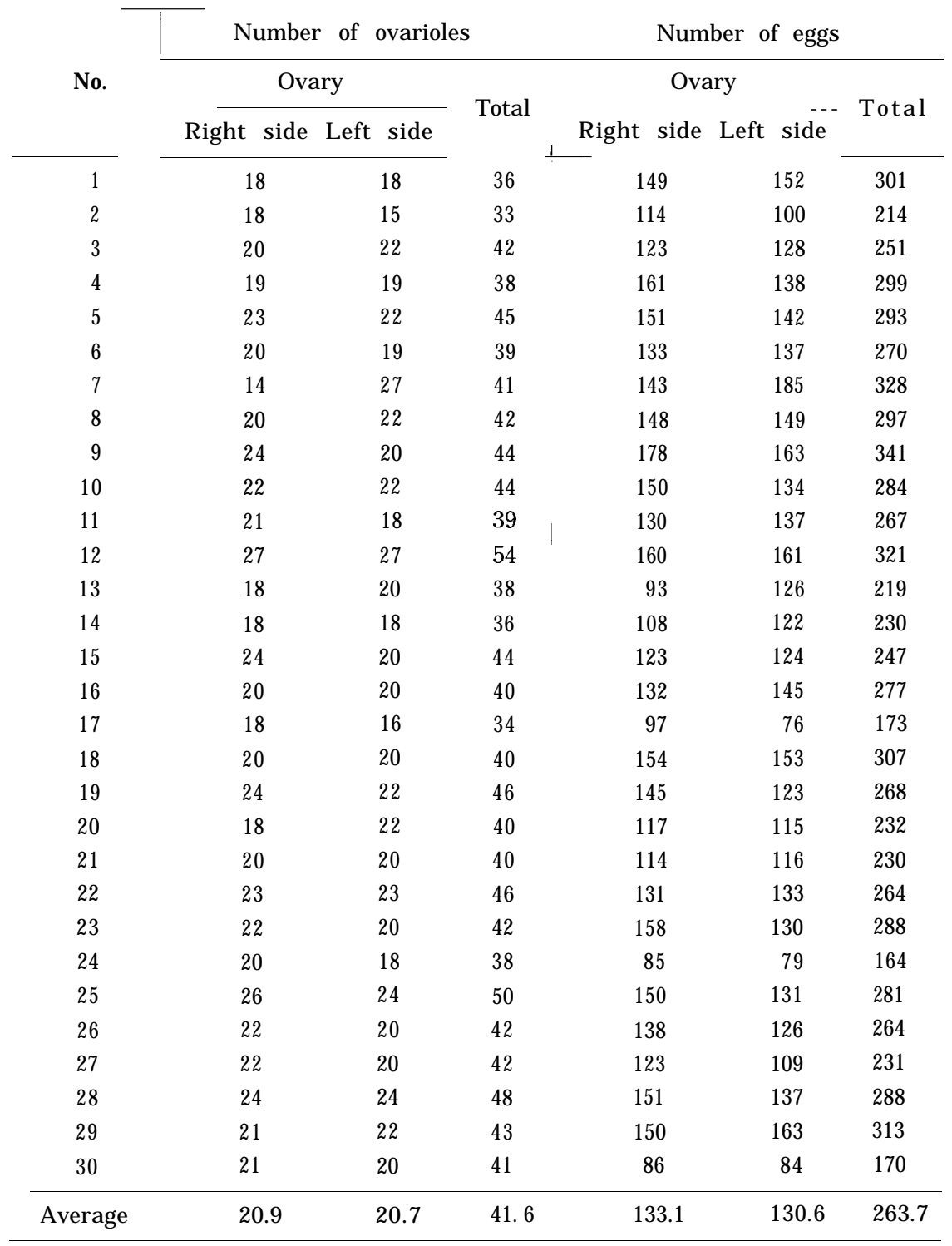




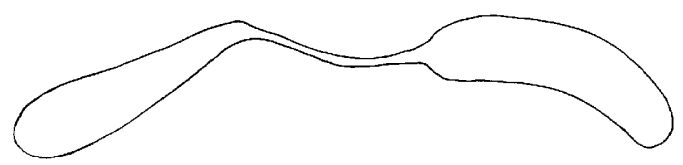

Fig. 7. Ovarian egg of $P$. natalis.

In most of the specimens, the coelom of body is almost occupied by the ovarioles. In P. natalis, the ovaries are composed of 42 ovarioles (20.9 on the right side, 20.7 on the left side). The number of ovarioles of both species seems different from each other, and in a few individuals they have the same numbers. But, in the statistical analysis, the chi-square test suggests that the deviation from expected value has no significant means. This means that the right side and left side ovaries are composed of the same number of ovarioles in expectancy. The average number of eggs in one ovariole is 6.3 , and the total number of eggs in each individual is 263.7. This figure 263.7 is rather smaller than in the other Cynipid wasps. The reason seems that this type of inquiline wasps (Periclistus) compels the gall maker to die, whereas the other inquiline wasps coexist with the gall maker within the same gall.

\section{Food-web surrounding Diplolepis japonica.}

The authors have found that the field population of Diplolepis japonica was extremely reduced by some natural enemies including the species of Periclistus, Eurytoma, Tetrastichus and an Ichneumon-fly. The ratio of occurrence of each species from the galls is shown as in Fig. 4. Thus the figures-parasites $8 \%$, inquilines $53 \%$ and gall maker $39 \%$-were observed. From the result obtained it was proved that more than half the population of Diplolepis japonica is controlled by the species of Periclistus. Careful observation of the food-web relation was also made for galls on Rosa polyantha Sieb. et Zucc. (Rosa multiflora Thunb.) and on Rosa rugosa Thunb. The authors could not find any inquilines and Ichneumon-flies from the galls of Diplolepis japonica on Rosa rugosa Thunb.

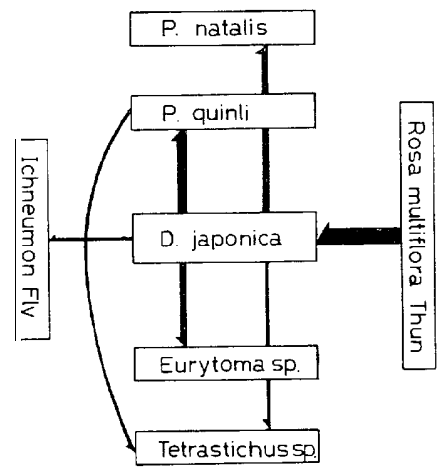

Fig. 8. Food-web surrounding D. japonica observed in the field. 


\section{Summary}

1. Two new species of the genus Periclistus are described from the specimens which were reared from the galls of Diplolepis japonica on Rosa polyantha.

2. Some remarkable biological differences between the two new species are reported. The morphology and the number of ovarian eggs are described and discussed.

3. Very interesting and peculiar phenomenon concerning the parasitic activity of the two new species is given with special reference to the galls of Diplolepis japonica produced on Rosa polyantha and on Rosa rugosa.

\section{References}

Dalla Torre, C. G. de et J. J. Kieffer 1910. Das Tierreich 24, Cynipidae :650-654. Eady, R. D. et J. Quinlan 1963. Handbooks for the identification of British insects. Hymenoptera Cynipoidea, $81 \mathrm{pp}$.

Weld, L. H. 1952. Cynipoidea (Hym.) 1905-1950: 266.

— 1959. Cynipid galls of the Eastern United States, 124 pp., 31 pls.

Yasumatsu, K. et A. Taketani 1967. Some remarks on the commonly known species of the genus Diplolepis Geoffroy in Japan. Esakia 6: 77-86, 4 pls. 